\title{
FRANCIJAS TIESĪBU IETEKME UZ IZMEKLĒŠANAS TIESNEŠA INSTITŪTA IZVEIDI KRIEVIJAS IMPĒRIJAS 1864. GADA TIESU REFORMAS IETVAROS
}

\section{IMPACT OF FRENCH LAW ON ESTABLISHMENT OF EXAMINING MAGISTRATE INSTITUTE IN FRAMEWORK OF 1864 JUDICIAL REFORM IN RUSSIAN EMPIRE}

\author{
Signe Skutele, Mg. iur. \\ Latvijas Universitātes Juridiskās fakultātes doktorante
}

\begin{abstract}
Summary
During the reform of 20 November 1864, emulating the most current Western European legal traditions, especially considering the example of France and its outlook on rights, the institute of examining magistrate was created in the Russian Empire. Originally intended as a judge with all related guarantees, ultimately, with the aid of the police, it ended up performing an investigation under the supervision of prosecutors. Consequently, the inquisitorial procedures secured substantial impact on preliminary criminal proceedings. In this article, the author focuses on the analysis of historical genesis of the examining magistrate institute in France and the Russian Empire, researching the impact of the French law pertaining to the examining magistrate established under the reforms in the Russian Empire and the differences between the two countries regarding nature of the institute.
\end{abstract}

Atslēgvārdi: izmeklēšanas tiesnesis, pirmstiesas kriminālprocess, 1864. gada reforma Krievijas impērijā.

Keywords: examining magistrate, preliminary criminal procedure, 1864 reform in the Russian Empire.

\section{Ievads}

Krievijas impērijā tika īstenota tiesu reforma, kuras laikā 1864. gada 20. novembrī pieņemts Tiesu iekārtas nolikums ${ }^{1}$ (turpmāk - 1864. gada Tiesu nolikums) un Kriminālprocesa nolikums ${ }^{2}$ (turpmāk - 1864. gada Kriminālprocesa nolikums). Šì reforma avotos tiek dēvēta par "dižo tiesu reformu”

\footnotetext{
1 Учрежденія судебныхъ установленій. [1864. red.] Сб. зак.: Полный сводъ законовъ Россійской Имперіи. Второе собрание (1825-1881), turpmāk - ПСЗ. Том 39. Часть 2. Закон № 41475, с. 180.

2 Уставъ Уголовнаго Судопроизводства. Сб. зак.: ПСЗ. Том 39. Часть 2. Закон № 41476, с. 215.

3 Давыдов Н. В. Уголовный суд в России. Москва: Грань, 1918, с. 184.
} 
būtiski pārveidota tiesu sistēma, ieviesti nozīmīgi tiesvedỉbas pamatprincipi un norisinājās tās modernizācija. ${ }^{4}$

N̦emot vērā to, ka Latvijas teritorija tajā laikā bija Krievijas impērijas sastāvāa, ${ }^{5}$ savukārt pēc Latvijas Republikas neatkarības pasludināšanas tika pieṇemti likumi, kuri nostiprināja kontinuitāti iepriekš spēkā bijušajiem normatīvajiem aktiem, ${ }^{6}$ tad vēsturiska izmeklēšanas tiesneša institūta izpēte ir nozīmīga arī mūsdienu Latvijas Republikas tiesību sistēmai, tostarp mācoties no pagātnes tiesību mantojuma.

Konstatējot, ka vēsturiski vienmēr ir pastāvējušas diskusijas par izmeklēšanas procesa kvalitātes uzlabošanu, tajā skaitā par tiesneša iespējamo lomu kriminālprocesā iepriekšèjās izmeklēšanas stadijā, publikācijā autore vēsturiski salīdzinošā kontekstā apskatīja izmeklēšanas tiesneša institūta izveidošanos reformas laikā Krievijas impērijā, ko lielā mērā ietekmēja Francijas tiesību sistēma.

\section{Rietumeiropas pieredzes nozīme}

Reformas kritiķi nereti norādīja, ka jaunie normatīvie akti ir vien "ārvalstu tēla produkts, kas ir pavisam nederīgs krievu dzivei" ". Kritiķu ieskatos tie bija tapuši "dažu tiesību zinātnieku [aizraušanās ar] franču grāmatiṇu lasīšanu rezultātā"».

Savukārt krievu publicists un valsts dienesta darbinieks Konstantīns Skalıovskis (Константи́н Аполло́нович Скалько́вский, 1843-1906) rakstīja, ka "mūsu juristi [..] vispār nemaz īpaši galvu nelauzijja - paṇēma un pārtulkoja, piemēram, Sardīnijas kriminālprocesa kodeksu [, veicot] daž[us] uzlabojum[us]"9. Tiesībzinātnieks Ivans Foin,ickis (Иван Яковлевич Фойниикий, 1847-1913) norādija, ka reformas veicēji "apzinājās citu tautu pastāvēšanu, kuras kultūras ziṇā bija vairāk attīstījušās un bija pelnījušas būt mūsu skolotāji, veidojot [..] jauno tiesisko kārtību"10. Tādējādi secināms, ka ne tikai Francijas pieredze tika ņemta par pamatu, veidojot jauno reformu.

No Krievijas impērijas tiesību zinātnieku darbiem ir redzams, ka viṇi skrupulozi analizējuši ārvalstu normatīvos aktus un to ieviešanas gaitu. ${ }^{11}$ Ârvalstu normatīvie akti tika arī tulkoti krievu valodā, publicēti ar Valsts kancelejas starpniecību, lai izmantotu tos kā materiālus darbam, vēl pirms reformas uzsākšanas. ${ }^{12}$

${ }^{4}$ Osipova S. Nācija, valoda, tiesiska valsts: ceḷā uz rītdienu. Rīga: Tiesu namu aǵentūra, 2020, 403. lpp.

5 Tomēr šīs reformas ietvaros pieņemtie normatīvie akti Latvijas teritorijā tika piemēroti tikai ar 1889. gada 9. jūliju, kad cars Aleksandrs III izdeva likumu par tiesu reformu Baltijas guberņās; sk.: Ķeisara Aleksandra II. Teesu Ustawi. Jelgawâ: H. Allunans, 1894; Kalniņš V. Latvijas PSR valsts un tiesību vēsture. I dalı. Rīga: Zvaigzne, 1972, 293. lpp.

${ }^{6}$ Likums par agrāko Krievijas likumu spēkā atstāšanu Latvijā. Likumu un Valdības rīkojumu krājums, 1919, 13. burtniza, dokumenta Nr. 154. Osipova S. 2020, 401. lpp.

7 Щегловитовь И. Г. Вліяніе иностранныхь законодательствъ на составленіе Судебныхъ Уставовъ 20 ноября 1864 года. Петроград: И. Д. Сытина, 1915, с. 12.

8 Ibid, c. 14 .

9 Ibid.

10 Ibid.

11 Sk. Фойницкій И. Я. Том I, Том II, 1910; Гартунгъ Н. Исторія уголовнаго судопроизводства и судоустройства Франціи, Англіи, Германіи и Россіи. Санктпетербург: Э Арнгольда, 1868; Щегловитовь И. Г., 1915.

12 Щегловитовь И. Г., 1915, с. 20.-22; Законы о судопроизводстве и судоустройстве Женевского Кантона. Материалы по судебной реформе в России 1864 года, turpmāk - Материалы. Том 38. Pieejams: https://www.prlib.ru/item/343176 [aplūkots 12.02.2021.]; Проект Бельгийского судоустройства, составленный в мае 1862 года Материалы. Том 39. Pieejams: https://www.prlib.ru/item/343149 [aplūkots 12.02.2021.]; Объяснительная записка къ проекту Устава уголовнаго судопроизводсива. 
Tādējādi reformas īstenotāji pētīja ne vien kontinentālās Eiropas tiesību loka valstu pieredzi, kurā pārsvarā tobrīd dominēja inkvizīcijas vai jauktais kriminālprocesuālais modelis, bet arī angloamerikāṇu tiesību loka sistēmas valstis, kas galvenokārt izmantoja sacīkstes jeb akuzācijas kriminālprocesa modeḷa principus.

Tomēr lielākā daḷa kontinentālās Rietumeiropas valstu, tostarp Krievijas impērija, pārņēma savos normatīvajos aktos tieši franču idejas jeb "nonāca franču kodifikācijas iespaidā, nomainot tīri inkvizìcijas procesuālo sistēmu uz jaukto sistēmu"13, protams, papildus veicot attiecīgas izmain̦as, lai tie organiski iekḷautos valsts pārvaldes iekārtā. Kā norādīja mūsdienu krievu tiesībzinātnieks Leonīds Golovko (Леонид Витальевич Головко, 1967), "tieši Francijā tika izveidota sākotnējās izmeklēšanas konstrukcija, kuras centrā ir izmeklēšanas tiesneša figūra"14.

\section{Francijas jauktās kriminālprocesuālās sistēmas izveide}

Avotos bieži tiek norādīts, ka pirms Lielās franču revolūcijas laikmeta bija raksturīga nevienlīdzība, autoritārisms un feodālisms. ${ }^{15}$ Jebkurā gadījumā pēc revolūcijas bija nepieciešams risināt dilemmu, kā savienot franču revolūcijā paustās idejas ar ilggadējām franču inkvizīcijas procesa tradīcijām, kas bija ietvertas arī līdz revolūcijai spēkā esošajā Kriminālajā ordonans $\mathrm{e}^{16} \cdot{ }^{17}$

Iepriekšéjo izpratni par kriminālprocesu būtiski ietekmēja filozofu, jo īpaši Monteskjē (Charles-Louis de Secondat, baron de Montesquieu, 1689-1755), Voltēra (Voltaire, 1694-1778) un Bekaria (Cesare Bonesana di Beccaria, 1738-1794) darbi. ${ }^{18}$ Šie filozofi jau iepriekš bija kritizējuši sava laika kriminālprocesuālo kārtību. Piemēram, Voltērs izteica cerību, ka "kādreiz humāni likumi mīkstinās dažas pārāk stingras paražas Francijā"19. Viṇaprāt, dažos jautājumos Kriminālā ordonanse bija vērsta tikai uz "apsūdzētā bojāeju”. Un, lai gan nozieguma izmeklēšana pieprasīja stingrību, “jo tas ir karš, kuru cilvēciskais taisnīgums ved ar l̦aunprātību, [tomēr] augstsirdība un līdzcietība pastāv pat karā"20. Savukārt Bekaria iestājās pret slepenību, saucot to ne tikai par l̦aunumu, bet arī tirānijas aizsargu. ${ }^{21}$

Nākot pie varas Napoleonam Bonapartam (Napoléon Bonaparte, 1769-1821), tika uzsākts darbs pie kodifikācijas, tostarp 1808. gada 18. novembrī pieṇemot

Материалы. Том 52. Pieejams: https://www.prlib.ru/item/343187 [aplūkots 12.02.2021.], c. 14, 19, 63, $156,358,435$.

13 Курс уголовного процесса. Москва: Статут, 2017, с. 138; Головко Л. В. Дознание и предварительное следствие в уголовном процессе Франции. Москва: СПАРК, 1995, с. 4.

14 Головко Л. В. 1995, с. 4.

15 Sk., piemēram, Hodgson J. French Criminal Justice. Oxford: Hart Publishing, 2005, p. 15.

16 Ordonnance Criminelle. [1670.red.] Pieejams: http://ledroitcriminel.fr/la_legislation_criminelle/anciens_ textes/ordonnance_criminelle_de_1670.htm [aplūkots 12.02.2021.].

17 Курс уголовного процесса. 2017, с. 137; Rusanovs E. Rietumeiropas vēsturiskās kriminālprocesa doktrīnas evolūcijas nekonsekvences un problēmas mūsdienu Latvijā. Grām.: Satversmē nostiprināto vērtību aizsardzība: dažādu tiesību nozaru perspektīva. Latvijas Universitātes 77. starptautiskās zinātniskās konferences rakstu krājums. Rīga: LU Akadēmiskais apgāds, 2019, 392. lpp.

18 Щегловитовь И. Г. 1915, с. 16. Гартунгъ Н. 1868, с. 49.

19 Вольтер. Избранные произведения по уголовному праву и процессу. Москва: Государственное издательство юридической литературы, 1956, с. 92.

20 Ibid.

21 Беккариа Ч. О преступлениях и наказаниях. Москва: Инфра-М, 2008, с. 107. 
Kriminālprocesa kodeksu ${ }^{22}$ (turpmāk - 1808. gada Kodekss). Šis 1808. gada Kodekss tika uzskatīts par minētās dilemmas atrisinājuma kompromisa variantu, ${ }^{23}$ vecā režīma inkvizīcijas kriminālprocesuālajā izpratnē ieviešot sacīkstes procesa elementus un izveidojot jaukto kriminālprocesuālo sistēmu. 1808. gada Kodekss bija spēkā līdz pat 1958. gadam, kad Francijas valstsvīra Šarla de Golla (Charles Andre Joseph Marie de Gaulle, 1890-1970) laikā izveidots jauns normatīvais regulējums, tomēr saglabājot izmeklēšanas tiesneša institūtu. ${ }^{24}$ Laika gaitā 1808. gada Kodeksā tika veikti vairāki grozījumi, tajā skaitā aizvien mazinot inkvizīcijas procesa elementus un paplašinot procesā iesaistīto personu tiesības.

1808. gada Kodekss veidots pēc stingras noziedzības kontroles no valsts puses. Tādējādi iepriekšējā izmeklēšana aizvien tika veikta inkvizīcijas modeḷa ietvaros. Tāpēc arī tajā nostiprinātais izmeklēšanas tiesneša institūts tiek atzìts par inkvizīcijas kriminālprocesa model̦a elementu. ${ }^{25}$

Tiesību literatūrā gan ir atrodamas ziņas par izmeklēšanas tiesnesim līdzīgu institūtu vēl pirms revolūcijas, tostarp radniecīgus institūtus konstatējot pat 14./15. gs. Francijā. ${ }^{26}$ Savukārt kopš 16. gs. Francijā bija kriminālleitnanti, kas tiek uzskatīti par izmeklēšanas tiesneša amata priekštečiem. ${ }^{27}$

\section{Izmeklēšanas tiesneša institūta izveide Krievijas impērijā}

Krievijas impērijas tiesībzinātnieks Ivans Ščeglovitovs (Ива́н Григópвевич Щеглови́тов, 1861-1918) atzina: "mūsu kriminālprocess, kā zināms, ir jauktais process, t. i., izmeklēšanas un sacīkstes procesa apvienojums. Šajā ziṇā varētu teikt, ka tas ir tuvs franču paraugam. Bet šì tuvība aprobežojas ar kopējām vadlīnijām, tā ka mūsu procesa būtỉba ievērojami atšķiras no franču tiesvedỉbas, pie tam uz lielākas pilnības pusi." ${ }^{28}$ Lai gan izmeklēšanas tiesneša institūts abu valstu kontekstā bija veidots visnotaḷ līdzịgi, ${ }^{29}$ abu valstu izpratne par izmeklēšanas tiesneša institūta būtību ievērojami atšḳīrās.

Izmeklēšanas reforma Krievijas impērijā notika vēl pirms 1864. gada 1860. gada 8. jūnijā, caram Aleksandram II pieņemot divus normatīvos aktus, ar kuriem daḷā Krievijas impērijas teritorijas tika izveidots izmeklēšanas tiesneša

22 Code d'instruction criminelle. [1808. red.] Pieejams: https://ledroitcriminel.fr/la_legislation_criminelle/ anciens_textes/code_instruction_criminelle_1808/code_instruction_criminelle_1.htm?fbclid= IwAR3S9qB-wa8z1LU36asdCj3Re9DZGvORayoXScJmABz5gFTRgYtdDf-TLZs [aplūkots 20.11.2020.].

${ }^{23}$ Berg R. K. Criminal Procedure: France, England, and the United States. Spring-Summer, Colume 8, Issue 2, 1959. Arti. 5, p. 283.

${ }^{24}$ Berg 1959, p. 284; Ruymbeke R. Le juge d'instruction. Paris: Presses Universitaires de France, 1988, p. 6.

25 Berg 1959, p. 298; Hodgson 2005, p. 27; Damaška M. The Faces of Justice and State Authority. New Haven: Yale University Press, 1986, p. 183.

${ }^{26}$ Delmas-Marty M., Spencer J. R. European Criminal Procedures. Cambridge: Cambridge Unviersity Press, 2005, p. 11; Милова И. Е. Следственный судья возрождение института. Pieejams: https://cyberleninka.ru/article/n/sledstvennyy-sudya-vozrozhdenie-instituta [aplūkots 20.11.2020.].

${ }^{27}$ Blot-Maccagnan S., Callemein G. Du lieutenant criminel au juge d'instruction. [B. v.]: Presses Universitaires de Rennes, 2018; Ruymbeke 1988, p. 6; Фойницкій И. Я. Том II, 1910, с. 348.

28 Щегловитовь И. Г. 1915, с. 50.

29 Фойницкій И. Я. Том I, 1910, с. 311; Щегловитовь И. Г. 1915, с. 39. 
institūts: Likums par izmeklēšanas tiesnešiem ${ }^{30}$ un Likums policijai par noziegumu un pārkāpumu izmeklēšanu. ${ }^{31}$

Avotos minēts, ka šis institūts ieviests tāpēc, ka 19. gs. pastāvēja neapmierinātība ar izmeklēšanu, ${ }^{32}$ kad izmeklēšanu veica no tiesu varas neatkarīgas amatpersonas, un tika uzskatīts - "lai izmeklēšana būtu pilnīga un pareiza, tai jābūt pilnībā pakḷautai tiesai, kā arī prokuroriem" 33 . Neapmierinātību radijjusi "patvaḷa, nelegālas izmeklēšanas metodes, faktiski apsūdzētā aizsardzības trūkums, kukuḷnemšana, nepamatota izmeklēšanas kavēšanās, garantiju trūkums par likuma pareizu piemērošanu, lai visi, kas izdarījuši noziegumu, tiktu pamatoti sodîti un neviena nevainīga persona netiktu saukta pie atbildības"34.

Tādējādi, vēloties "dot policijai vairāk līdzekḷu, lai veiksmīgāk veiktu savus pienākumus, kas tik svarīgi visu iedzīvotāju kārtībai un mieram" ${ }^{35}$, tika nolemts atdalīt izmeklēšanas daḷu no policijas četrās impērijas guberņās. Tajās visu noziegumu un pārkāpumu izmeklēšanai tika ieceltas īpašas, tieslietu ministram pakḷautas amatpersonas, kuras piekritīgas tiesu vietām, nosaucot šīs amatpersonas par izmeklēšanas tiesnešiem.

Līdz ar to šis institūts Krievijas impērijā tika ieviests jau 1860. gadā. Tomēr pilnvērtīgi tas nostiprinājās, veicot 1864. gada reformu, kuras laikā tika radīts tāds regulējums, kas l̦āva izmeklēšanas tiesnešiem veikt savas funkcijas "pilnā apjomā, nodrošinot šì institūta harmonisku iekḷaušanos jaunajā kriminālprocesā"36.

\section{Izmeklēšanas tiesneša institūta pamataspekti}

Saskaṇā ar Francijas un Krievijas impērijas normatīvajiem aktiem izmeklēšanas tiesnesis bija paredzēts kā neatkarīgs institūts, kas godprātīgi, vispārīgi un bez aizspriedumiem ar policijas, kura veica izziņas darbības, palīdzību veiktu noziegumu un kriminālpārkāpumu izmeklēšanu stingrā prokurora uzraudzībā.

Francijas 1808. gada Kodeksā izmeklēšanas tiesnesis tika uzskaitīts pie tiesu policijas institūtiem. ${ }^{37}$ Katrā Francijas municipālajā apgabalā bija noteikts skaits izmeklēšanas tiesnešu. ${ }^{38}$ Savukārt 1864. gada Tiesu nolikumā tika noteikts, ka izmeklēšanas tiesneši tiek uzskatīti par apgabaltiesas locekḷiem, un katram no viņiem tika piešķirts savs iecirknis. ${ }^{39}$

30 Учреждение Судебныхь Следователей. [1860. red.] Сб. зак.: ПСЗ. Том 35. Часть 1. Закон № 35891, c. 710 .

31 Наказъ полиций о производстве могущим заключать въ себе преступление и проступокъ. [1860. red.] Сб. зак.: ПСЗ. Закон № 35892, с. 715.

32 Ахмедов Ч. Н. Судебный следователь в правоохранительной системе России: становление, развитие и законодательное оформление его деятельности. Вестник Санкт-Петербургского университета МВД России № 3 (63) 2014, с. 11.

33 Судебные уставы 20 ноября 1864 года. Съ изложениемъ рассуждений на конъ они основаны. Часть II. Санктпетербург: Государственная Канцелярия, 1866, с. 111.

34 Волчкова А. А. Институт судебных следователей в дореволуционной России (Историческиправовой анализ). Автореферат диссертации на соискание ученой степени кандидата юридических наук. Нижний Новгород: [b. i.], 2005, c. 15.

35 Наказъ Судебнымъ следовательям. [1860. red.] Сб. зак.: ПСЗ. Том 35. Часть 1. Закон № 35890, с. 710.

36 Волчкова А. А. 2005, с. 12.

37 9. pants. Code d'instruction criminelle. [1808. red.]

38 55. pants. Code d'instruction criminelle. [1808. red.]

39 79. pants. Учрежденія судебныхъ установленій. [1864. red.] 
Abās valstīs izmeklēšanas tiesnesis varēja veikt arī tiesas spriešanas funkcijas. Piemēram, 1808. gada Kodeksā norādīts, ka Francijā viņš turpināja izskatīt civillietas, ${ }^{40}$ savukārt Krievijas impērijā izmeklēšanas tiesnesis, ja trūka tiesnešu un nebija iespējams sasaukt tiesas sēdi, varēja tikt aicināts skatīt arī krimināllietas, kuras pats nebija izmeklējis. ${ }^{41}$

Saskanā ar 1808. gada Kodeksa 55. pantu Francijā izmeklēšanas tiesnešus uz trīs gadiem (ar iespēju pagarināt termiṇu) iecēla imperators no civiltiesu tiesnešiem. Mainoties Francijas valsts pārvaldes iekārtai un pēc 1856. gada grozījumiem, ${ }^{42}$ izmeklēšanas tiesnesi ar dekrētu iecēla valdība no "titulētiem tiesnešiem vai tiesnešu vietniekiem”. Savukārt 1864. gada Tiesu nolikuma 212. pantā tika noteikts, ka izmeklēšanas tiesnešus iecel, cars pēc tieslietu ministra ieteikuma. Krievijas impērijā tika apsvērts, ka izmeklēšanas tiesneši būtu jāiecel̦ tieslietu ministram. Tomēr, ņemot vērā to piederību pie apgabaltiesām, kā arī to, ka pastāvēja noteiktas situācijas, kad izmeklēšanas tiesneši varēja piedalìties iztiesāšanā, bet vēl jo vairāk to, ka reformas ietvaros tiesu un administratīvā vara tika nošķirta, šāds regulējums netika pieņemts. ${ }^{43}$ Atšķirībā no Francijas izmeklēšanas tiesnesis Krievijas impērijā netika iecelts uz noteiktu termiņu un uz šo amatu varēja kandidēt ne tikai tās personas, kas jau ieṇēma tiesneša amatu. ${ }^{44}$

Saskaņā ar abu valstu normatīvajiem aktiem, veicot izmeklēšanas darbības, izmeklēšanas tiesnesis bija prokuratūras uzraudzībāa, ${ }^{45}$ tostarp viṇam bija jāziṇo prokuroram par procesa uzsākšanu un pabeigšanu. ${ }^{46} \mathrm{I}$. Ščeglovitovs gan rakstīja, ka, atšķirībā no franču kriminālprocesa, Krievijas impērijā attiecībā uz prokuratūras uzraudzību izmeklēšanas tiesneši savās darbībās tomēr bijuši patstāvīgāki un neatkarīgāki. ${ }^{47}$ Acīmredzot viņš norādīja uz 1808. gada Kodeksa darbības laiku līdz 1856. gada grozījumiem, pēc kuriem izmeklēšanas tiesneši savās darbībās tomēr kḷuva patstāvīgāki. ${ }^{48}$

Izmeklēšanas tiesneša darbību kontrolēja arī tiesnešu koleg̣iālas institūcijas. Francijā 1808. gada Kodeksā līdz 1856. gada grozijumiem bija noteikts, ka izmeklēšanas tiesnesim vismaz vienu reizi nedẹlā jāziņo par savu darbību padomes palātai, kas saskaṇā ar 127. pantu sastāvēja no trīs tiesnešiem, ieskaitot izmeklēšanas tiesnesi. Ja padome neuzskatīja izmeklējamo darbību par noziedzīgu vai aizdomās turēto par iespējamo vainīgo, tā varēja izbeigt izmeklēšanu. Pēc 1856. gada grozījumiem tika ievērojami palielināta izmeklēšanas tiesneša loma, tomēr, tiklīdz izmeklēšanas tiesnesis bija pabeidzis savu darbu, viṇš ziṇoja prokuroram, kurš savukārt veica lietas pārbaudi un nosūtīja lietu uz tiesu vai atpakaḷ izmeklēšanai. ${ }^{49}$ Savukārt

\footnotetext{
40 55. pants. Code d'instruction criminelle. [1808. red.]

41 145.-147. pants. Учрежденія судебныхъ установленій. [1864. red.]

42 Code d'instruction criminelle. [1929. red.] Pieejams: https://ledroitcriminel.fr/la_legislation_criminelle/ anciens_textes/code_instruction_criminelle_1929/code_1808_1.htm [aplūkots 20.11.2020.].

43 Судебные уставы 20 ноября 1864 года. Часть III, 1867, с. 141.

44 201.-212. pants. Учрежденія судебныхъ установленій. [1864. red.]; Фойницкій И. Я. Том I., 1910, c. 410 .

45 57. pants. Code d'instruction criminelle. [1808. red.]; 249. pants. Уставъ Уголовнаго Судопроизводства. [1864. red.]

46 61. pants. Code d'instruction criminelle. [1808. un 1929. red.]; 263, 277. pants. Уставъ Уголовнаго Судопроизводства. [1864. red.]

47 Щегловитовь И. Г. 1915, с. 39.

48 Hodgson 2005, pp. 27-28.

49 127. pants. Code d'instruction criminelle. [1929. red.]
} 
ar grozījumiem 128. pantā tika noteikts, ka tieši izmeklēšanas tiesnesis pats ar savu rīkojumu varēja izbeigt lietas izmeklēšanu.

Toties Krievijas impērijā saskaṇā ar 1864. gada Kriminālprocesa nolikuma 278. pantu izmeklēšanu varēja izbeigt tikai tiesa. Līdz ar to, kad izmeklēšanas tiesnesis vairs neredzēja nepieciešamību turpināt izmeklēšanu, vin̄š ar prokurora starpniecību vērsās pie tiesas.

Tādējādi secināms, ka Krievijas impērijā izmeklēšanas tiesneša institūts, lai gan veidojās Rietumeiropas kriminālprocesuālo modeḷu ietekmē, tostarp modificējot franču tiesību izpratni, kā inkvizīcijas procesa komponente labi iederējās arī Krievijas impērijas monarhistiskajā pārvaldē 19. gadsimtā.

Tieši šis modelis arī tika implementēts jau demokrātiskās un neatkarīgās Latvijas Republikas normatīvajā regulējumā.

\section{Kopsavilkums}

1. Krievijas impērijā, izstrādājot 1864. gada 20. novembra reformu, tika pievērsta uzmanība ārvalstu normatīvajam regulējumam un sekots jaunākajām tiesvedības attīstības tendencēm Eiropā, tajā skaitā modernizējot kriminālprocesuālo tiesvedỉbu.

2. Napoleona laikā, kad notika darbs pie kodifikācijas, tika ieviests izmeklēšanas tiesneša institūts, kura prototipi Francijā konstatējami vēl pirms Lielās franču revolūcijas. Izmeklēšanas tiesneši gan joprojām bija inkvizīcijas procesa elements, kas apvienoja gan izmeklēšanas, gan tiesneša funkcijas.

3. Reforma Krievijas impērijā risinājās vēl pirms 1864. gada, atsevišḳās tās daḷās jau 1860. gadā ieviešot izmeklēšanas tiesneša institūtu. Tomēr tikai pēc 1864. gada to iedibināja visā impērijā ar atsevišķiem izṇēmumiem. Vienlaikus tam tika piešksirta lielāka neatkarỉba un paplašināta rīcības brīvība. Lai gan izmeklēšanas tiesnešu amati tika izveidoti, ņemot vērā Francijas kriminālprocesuālo regulējumu, pastāvēja atšķirības abu valstu izpratnē par šì institūta būtību.

4. Jāsecina, ka, neraugoties uz centieniem izmeklēšanas tiesnesim piešķirt tiesas institucionalitāti un uzlabot iepriekšējās izmeklēšanas kvalitāti, tomēr vēsturiski gan Francijā, gan Krievijā izmeklēšanas tiesnesis nevarētu tikt uzskatīts par pilnvērtīgu tiesu varas pārstāvi, ievērojot tā ierobežotās pilnvaras. Tādējādi arī radot strīdus par paša institūta jēgu un lomu. 